\title{
EFFECT OF PARTIAL REPLACEMENT OF SAND WITH QUARRY DUST ON THE STRUCTURAL CHARACTERISTICS OF SANDCRETE BLOCKS
}

\author{
C. U. Anya ${ }^{1,{ }^{*}}$ and N. N. Osadebe ${ }^{2}$ \\ 1 DEPARTMENT OF CiVIL ENGINEERING, FEDERAL UNIVERSITY OF TECHNOLOGY, OWERRI, IMO STATE. NIGERIA \\ 2 DEPARTMENT OF Civil ENGINEERING, UNIVERSITY OF NigERIA, NSUKKA, ENUGU STATE. NIGERIA

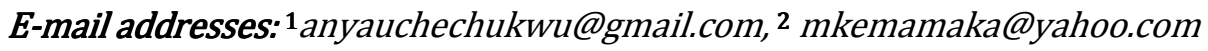

\begin{abstract}
This work investigated the effect of partial replacement of sand with quarry dust on the compressive strength, flexural strength, split tensile strength and water absorption of sandcrete blocks. River sand was replaced with quarry dust at percentages ranging from 0 to 40 at cement/combined aggregate ratio of 1: 6 . The blocks were moulded using a Rosa Commetta block laying machine and were tested after curing by water sprinkling for 28 days. The results showed that the inclusion of quarry dust improved the properties, with the highest improvement being at 40\% replacement for all the properties. The compressive strength, flexural strength and split tensile strength increased by 27, 38 and 19\% respectively at 40\% replacement.The compressive strength and water absorption of the blocks also met the minimum Nigerian Industrial Standard's requirement of $3.45 \mathrm{~N} / \mathrm{mm}^{-2}$ and $12 \%$ for vibrated blocks respectively. The results also showed that blocks produced with quarry dust as the sole aggregate have lower qualities than sandcrete blocks of the same mix. It is recommended that partial replacement of sand with quarry dust in sandcrete block production be encouraged as it reduces the excessive demand for river sand and its attendant problems while providing a useful means of utilizing the excess quarry dust produced which, if left to accumulate in large quantities, constitute great environmental hazard.
\end{abstract}

Keywords: Sand-quarry dust block, sandcrete block, compressive strength, flexural strength, split tensile strength, water absorption, environmental hazard.

\section{INTRODUCTION}

Sandcrete blocks are the most common type of blocks used in forming walls in modern day Nigeria. Their popularity is due to their great ease in production and placing. They are produced by compacting a mixture of water, cement and sand in suitable proportions, in a mould such that the green blocks which are removed from the mould immediately after compaction are self-supporting; hence they are often referred to as zero-slump concrete. The main source of sand for sandcrete block production is river. The great infrastructural development in the world generally has led to a high rate of depletion of river sand with the attendant problem of environmental degradation $[1,2,3]$. To stem the tide in environmental degradation as a result of uncontrolled sand mining, many government agencies have placed strict regulations on river sand mining. For example, some sand mining sites within the campus of the Federal University of Technology, Owerri, Nigeria were closed as a result of the environmental problems they caused [4]. Similarly, it is reported [5] that for the same reason, the government of Sri Lanka banned sand mining in some identified areas of major rivers.This has led to scarcity and an increase in the cost of quality river sand for sandcrete block production and a search for alternatives to replace sand, either partially or wholly. One of such alternatives is quarry dust, a by-product of rock quarrying. Large volumes of quarry dust are produced during the quarrying of rock for coarse aggregate production. The amount of quarry dust from the crushing process is about 20 $25 \%$ of the final product from stone crushing units [1, 2]. Only a little portion of the quarry dust is utilized as a filler in wearing courses of asphalt pavements. Use must therefore be found for the large volumes of quarry dust remaining in order that they do not constitute another environmental hazard. It is this that led researchers into incorporating quarry dust as a partial replacement of river sand in sandcrete block 
production. Sand-quarry dust block is sandcrete blocks in which the sand has been partially replaced with quarry dust.

Much work has been done on the partial replacement of sand with quarry dust in construction. These works focused primarily on concrete production $[3,6,7,8]$. Works by [9] and [10] are among the few on the effect of partial replacement of sand with quarry dust in the production of sandcrete blocks. Again these works focused more on the compressive strength and water absorption of the blocks. The objective of this work is to investigate the effect of partial replacement of river sand with quarry dust on the compressive strength, flexural strength, split tensile strength and water absorption of sandcrete blocks.

\section{MATERIALS AND METHODS}

\subsection{Materials and Physical Tests}

The materials used for this work are Water, Cement, Sand and Quarry dust. Potable water obtained from a borehole was used in all the processes of manufacture and curing of blocks. Ibeto brand of Ordinary Portland cement which conformed to [11] was used. River sand was obtained from Otamiri River at Ihiagwa, Owerri, Imo State, Nigeria. Quarry dust was obtained from the quarry plant of Crushed Rock Industries, Ishiagu, Ebonyi State, Nigeria. Sieve analyses of the sand and the quarry dust were in accordance to [12].The specific gravities of the samples were determined using a pyknometer bottle of 1 litre capacity. The weight of the clean empty bottle, $M_{1}$, was first determined. The bottle was then filled to about a third of its capacity with the dry aggregate sample and the weight, $M_{2}$, determined. The bottle and its content was filled to three-quarter full with distilled water. A rod was used to stir the content to remove entrapped air after which it was filled to capacity with distilled water. The weight of the bottle and its contents, $M_{3}$, was then recorded. The bottle was then emptied, cleaned, refilled with distilled water and the resulting weight, $M_{4}$, recorded. The specific gravity, $G_{s}$, was determined as:

$$
G_{s}=\frac{M_{2}-M_{1}}{\left(M_{4}-M_{1}\right)-\left(M_{3}-M_{2}\right)}
$$

Three trials were conducted and the average taken as the specific gravity of the sample.

The bulk density was determined using a graduated measuring cylinder of 1 litre capacity. The weight of the empty cylinder, $M_{1}$, was determined. It was then filled with some soil sample (one-third to two-third full). The weight of the soil and cylinder, $M_{2}$, was recorded. The bulk density, $\rho$ was obtained by dividing the weight of the sample by the volume, $V$, it occupied.That is:

$$
\rho=\frac{M_{2-} M_{1}}{V}
$$

\subsection{Mix Proportions}

Batching of the constituents was by weight. The cement/combined aggregate ratio for all the mixes was 1: 6 . Sand was partially replaced with quarry dust at the following percentages: $0,10,20,30,40$ and 100 . The fine aggregates were used in their dry condition.

\subsection{Sample Preparations and Testing 2.3.1 Compressive strength and Water absorption}

Six hollow blocks of dimension $450 \times 225 \times 225 \mathrm{~mm}$ with a surface area of the solid portion of $56880 \mathrm{~mm}^{2}$, representing $56 \%$ of the overall surface area of the block were produced for each percentage sand replacement. The blocks were made using a Rosa Commetta block moulding machine. Batching was by weight using a weighing balance of $50 \mathrm{~kg}$ capacity. Mixing of the constituents was done manually using shovels. First, the sand and the quarry dust which had been previously completely dried were mixed to a constant colour. Cement was then added and the whole process of mixing continued until a uniform colour was achieved. Water was finally added and the mixing continued until the colour of the paste was uniform. The mixture was then loaded into the moulds of the machine where they were vibrated, compacted and demoulded immediately. The blocks were cured for 28 days by sprinkling them with water twice daily. Three of the blocks were subjected to compressive strength test in a universal testing machine to determine their compressive strength while the other three were used for the water absorption test. The compressive strength, $Y_{c}$ of the blocks were determined from the relationship:

$$
Y c=\frac{\text { Crushing load }(N)}{\text { Cross }- \text { sectional area of block }\left(\mathrm{mm}^{2}\right)}
$$

For the water absorption test, the cured blocks were dried to constant mass after which they were completely immersed in water for 24 hours. The blocks were weighed after removing the surface water with a towel. The water absorption, $\left(W_{a}\right)$ of the block was calculated as the difference between the mass of the saturated block, $M W$ and the dry mass, $M_{d}$ expressed as a percentage of the dry mass. That is:

$$
W_{a}=\frac{M_{w}-M_{d}}{M_{d}} \times 100 \%
$$




\subsubsection{Flexural strength}

The flexural strength test was done in accordance to [13] and [14] using test specimens of $600 \times 150 \times$ $150 \mathrm{~mm}$ dimensions. The three point load system was used and the flexural strength determined using the relationship:

$$
F_{l}=\frac{F a}{b d^{2}}
$$

In (5), $F_{1}$ is the flexural strength, $F$ is the failure load, a is the span of the beam, $b$ is the width of the beam, $d$ is the depth of the beam.

Three samples were tested for each mix and the average taken as the flexural strength for the mix.

\subsubsection{Split tensile strength}

The split tensile strength test was carried out on cylinders $300 \times 150 \mathrm{~mm}$ diameter in accordance to the requirements of [13] and [15]. The split tensile stress was calculated using the relationship:

$$
F s t=\frac{2 F}{\pi L d}
$$

Here, $F_{\text {st }}$ is split tensile strength, $F$ is failure load, $L$ is the length of specimen, $d$ is the diameter of the specimen.

\section{RESULTS AND DISCUSSION}

The results of the specific gravity tests on the river sand and the quarry dust are presented in Tables 1 and 2 respectively while the corresponding results for the bulk densities are shown in Tables 3 and 4. The gradation curves of the sand and quarry dust are as shown in Fig. 1.

Table 1: Specific gravity of sand

\begin{tabular}{lccc}
\hline Trial run & Trial 1 & Trial 2 & Trial 3 \\
\hline Mass of empty pyknometer bottle $\left[M_{1}\right],(\mathrm{g})$ & 443 & 443 & 443 \\
Mass of bottle + dry sample [ $\left.M_{2}\right],(\mathrm{g})$ & 900 & 959 & 932 \\
Mass of bottle + dry sample + water [ $\left.M_{3}\right],(\mathrm{g})$ & 1757 & 1791 & 1774 \\
Mass of bottle filled with water only [ $\left.M_{4}\right],(\mathrm{g})$ & 1471 & 1471 & 1471 \\
Specific Gravity, $\quad G_{s}=\frac{M_{2}-M_{1}}{\left(M_{4}-M_{1}\right)-\left(M_{3}-M_{2}\right)}$ & 2.673 & 2.649 & 2.629 \\
\multicolumn{2}{c}{ Average Specific gravity $=2.65$} & & \\
\end{tabular}

Table 2: Specific gravity of quarry dust

\begin{tabular}{lccc}
\hline Trial run & Trial 1 & Trial 2 & Trial 3 \\
\hline Mass of empty pyknometer bottle $\left[M_{1}\right],(\mathrm{g})$ & 443 & 443 & 443 \\
Mass of bottle + dry sample [ $\left.M_{2}\right],(\mathrm{g})$ & 978 & 1006 & 986 \\
Mass of bottle + dry sample + water [ $\left.M_{3}\right],(\mathrm{g})$ & 1820 & 1849 & 1834 \\
Mass of bottle filled with water only $\left[M_{4}\right],(\mathrm{g})$ & 1471 & 1471 & 1471 \\
Specific Gravity, $\quad G_{S}=\frac{M_{2}-M_{1}}{\left(M_{4}-M_{1}\right)-\left(M_{3}-M_{2}\right)}$ & 2.76 & 2.75 & 2.72 \\
\multicolumn{2}{c}{ Average Specific gravity $=2.74$} \\
\hline
\end{tabular}

Table 3: Bulk density of sand

\begin{tabular}{llll}
\hline Test run & 1 & 2 & 3 \\
\hline Mass of soil, $M(\mathrm{~kg})$ & 0.055 & 0.0625 & 0.0732 \\
Volume occupied, $V\left(\mathrm{~m}^{3}\right)$ & 0.000035 & 0.00004 & 0.000047 \\
Bulk density, $=M / V\left(\mathrm{~kg} / \mathrm{m}^{3}\right)$ & 1571 & 1563 & 1557 \\
Average bulk density, $\rho,\left(\mathrm{kg} / \mathrm{m}^{3}\right)$ & 1564 & & \\
\hline
\end{tabular}

Table 4: Bulk density of quarry dust

\begin{tabular}{llll}
\hline Test run & 1 & 2 & 3 \\
\hline Mass of soil, $M(\mathrm{~kg})$ & 0.045 & 0.0517 & 0.072 \\
Volume occupied, $V\left(\mathrm{~m}^{3}\right)$ & 0.000035 & 0.00004 & 0.00005 \\
Bulk density, $=M / V\left(\mathrm{~kg} / \mathrm{m}^{3}\right)$ & 1286 & 1293 & 1309 \\
Average bulk density, $\rho,\left(\mathrm{kg} / \mathrm{m}^{3}\right)$ & 1296 & & \\
\hline
\end{tabular}




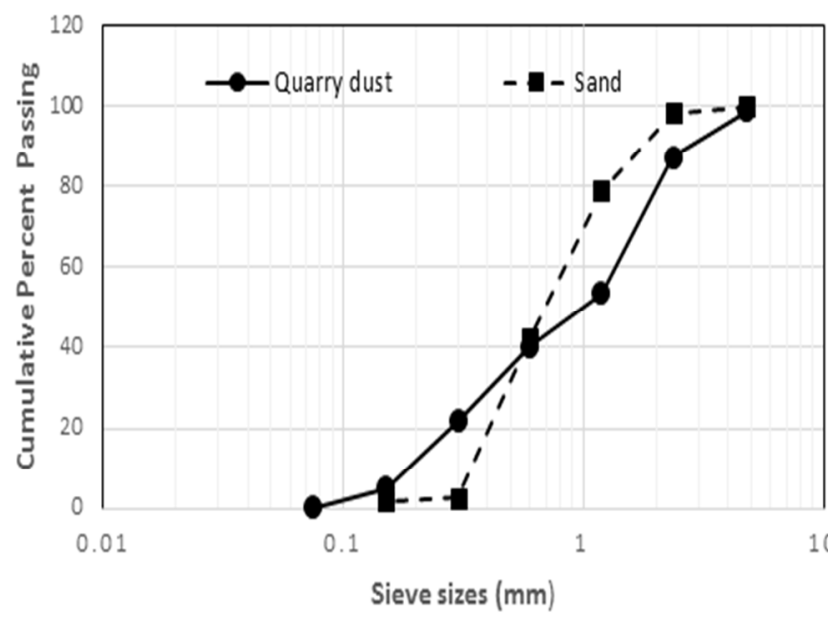

Fig. 1: Grading curves of river sand and quarry dust.

The specific gravities of the river sand and the quarry dust were found to be 2.65 and 2.74 respectively. These values are within the normal ranges for the respective materials. Values of specific gravity of quarry dust obtained from literature varies, depending on the gradation and the parent rocks. A value of 2.71 was obtained in [16]. The bulk densities of the river sand and the quarry dust were respectively 1564 and $1296 \mathrm{~kg} / \mathrm{m}^{3}$. Again these figures compare favourably with those in the literature. Values of 1460 and $1230 \mathrm{~kg} / \mathrm{m}^{3}$ respectively were obtained in [17].

The values of coefficient of gradation, $C_{c}$, and coefficient of uniformity, $C_{u}$, obtained from Fig. 1 for the river sand are respectively 0.97 and 2.24. These values indicate that the sand is well graded $\left(\mathrm{C}_{\mathrm{c}}\right.$ is approximately 1) but with a small range of particle size. The corresponding values for the quarry dust are 0.65 and 6.84. The quarry dust is therefore poorly graded, but with a higher range of particle size.

The values of the fineness moduli obtained for the sand and quarry dust from the sieve analysis are respectively 2.79 and 2.93 . These values are within the range of 2.31 - 3.1 recommended for fine aggregates for concrete works [18]. Both aggregates also fall into zone 2 of the grading requirements for fine aggregates and are suitable for block production [19].

The results of the various strength and water absorption tests are presented in Table 5 while the variation of the various strength parameters with the percentage replacement of sand is shown in Fig. 2. The variation of water absorption with percent replacement of sand is shown in Fig. 3.

It is seen from Table 5 that the inclusion of quarry dust in the mix improved all the strength parameters tested, the optimum replacement being at $40 \%$ for all the strength parameters. At $40 \%$ replacement a compressive strength of $5.23 \mathrm{Nmm}^{-2}$, which is 27 and $38 \%$ respectively higher than that at $0 \%\left(4.12 \mathrm{Nmm}^{-2}\right)$ and $100 \%\left(3.79 \mathrm{Nmm}^{-2}\right)$ replacement of sand, was observed. The continuous increase in strength with increase in percent replacement of sand, up to $40 \%$, is similar to the results obtained previously [7], albeit for mortar and concrete cubes.

The optimum percent replacement of $40 \%$ is higher than the $15 \%$ obtained by $[9,10]$. The results also showed a marked difference from those obtained by Boeck et al. [20] in which the inclusion of quarry dust did not improve the compressive strength of cylindrical solid blocks of $101.4 \mathrm{~mm}$ diameter and $116.8 \mathrm{~mm}$ high. The differences in the results can be attributed to the differences in the gradation of the sand and the quarry dust used in the various works. The quarry dust used in this work is poorly graded while that used in [10] is well graded. The sand used by Boeck et al. [20] falls within the grading limit of Zone 1 and is coarser than that used in this work. It should be noted, however, that quarry dust is typically poorly graded.

Table 5: Results of experimental tests

\begin{tabular}{ccccc}
\hline $\begin{array}{c}\text { Percent Replacement of } \\
\text { sand }\end{array}$ & $\begin{array}{c}\text { Compressive strength } \\
\left(\text { Nmm }^{-2}\right)\end{array}$ & $\begin{array}{c}\text { Flexural strength } \\
\left(\text { Nmm }^{-2}\right)\end{array}$ & $\begin{array}{c}\text { Split tensile strength } \\
\left(\text { Nmm }^{-2}\right)\end{array}$ & $\begin{array}{c}\text { Water absorption } \\
(\%)\end{array}$ \\
\hline 0 & 4.12 & 3.13 & 2.81 & 4.50 \\
10 & 4.57 & 3.48 & 2.92 & 4.26 \\
20 & 4.74 & 3.78 & 3.06 & 3.78 \\
30 & 4.97 & 4.00 & 3.20 & 3.44 \\
40 & 5.23 & 4.19 & 3.33 & 3.20 \\
100 (Quarry dust only) & 3.79 & 2.93 & 2.71 & 5.21 \\
\hline
\end{tabular}


At $40 \%$ replacement, the flexural strength increased by $38 \%$ compared to when only sand was used as the sole aggregate. The corresponding percentage increase for the split tensile strength was 19\%.

The inclusion of quarry dust reduced the water absorption of the blocks, thus improving the durability of the blocks. There was a steady reduction in the water absorption as the percent replacement of sand increased from 0 to $40 \%$, again the optimum value being at $40 \%$ replacement. The water absorption at $40 \%$ replacement was 29 and $39 \%$ lower than when only sand (0\% replacement) and quarry dust (100\% replacement) were used respectively. The lower strength and higher water absorption values observed when only quarry dust was used may be attributed to the fact that the quarry dust is poorly graded since it has a coefficient of gradation of only 0.65 . It should be noted, however, that all the samples met the maximum water absorption requirement of $12 \%$ and minimum compressive strength of $3.45 \mathrm{Nmm}^{-2}$ for vibrated sandcrete blocks as recommended by the Nigerian Industrial Standards [19]. There is no recommended minimum value for the flexural and split tensile strengths of sandcrete blocks.

\section{CONCLUSION AND RECOMMENDATION}

The partial replacement of sand with quarry dust in sandcrete block production has been shown to improve the structural properties of the blocks. The optimum percent replacement depends on the gradation of the quarry dust. The inclusion of quarry dust in sandcrete block should be encouraged as this will greatly reduce excessive river sand mining while providing a means of effectively utilizing the excess quarry dust produced in the quarry sites. By this practice environmental hazard arising from excessive sand mining and accumulation of large volume of quarry dust will be greatly reduced. However, trial tests must be conducted in order to determine the ideal percentage replacement of sand for improved block properties. It is also recommended that further works be carried out to investigate how the structural properties of the blocks are affected with the different gradations of river sand and quarry dust.

\section{ACKNOWLEDGEMENT}

Mr. Ifeanyi Diogu of ACI Blocks Owerri gave us free use of his facilities including the Rosa Commetta Block moulding machine for which we remain ever grateful.

\section{REFERENCES}

[1] Shridaran, A., Soosan, T. G., Jose, T. and Abraham B. M. (2006): Shear strength studies on soil quarry dust mixtures. Geotechnical and Geological Engineering. 24 (5) 1163 - 1179.

[2] Venkata S. K. N., Rao, P. B. and Krishna S. M. L. N. (2013): Experimental study on partial replacement of cement with quarry dust. International Journal of Advanced Engineering Research and Studies 2 (3) 136-137.

[3] Celik, T. and Mara, K. (1996): Effects of crushed stone dust on some properties of concrete. Cement and Concrete Research, 26 (7) 1121 - 1130.

[4] Anya, C. U. (2015). Models for predicting the structural characteristics of sand-quarry dust blocks. Unpublished Ph.D thesis, Department of Civil Engineering, University of Nigeria, Nsukka.

[5] Jaywardena, U. De S. and Dissanayake, D. M. S. (2006). Use of quarry dust instead of river sand for future constructions in Sri Lanka. IAEG Paper No 38. The Geological Society of London pp1 - 4.

[6] Manasseh J. (2010): Use of crushed granite fine as replacement to river sand in concrete production, Leonardo electronics journal of practice and technologies, Issue 17, 85 - 96.

[7] Nagabhushana and Sharada bai, H. (2011): Use of crushed rock powder as replacement of fine aggregate in mortar and concrete. Indian Journal of Science and Technology.4 (8) 917 - 922.

[8] Sukesh, C., Krishna, K. B., Teja, P. S. S. and Rao, S. K., (2013). Partial Replacement of Sand with Quarry Dust in Concrete. International Journal of Innovative Technology and Exploring Engineering (IJITEE) ISSN: 2278-3075, 2 (6)254 - 258.

[9] Oyekan, G. L. and Kamiyo, O. M (2008): Effects of granite fines on the structural and hygrothermal properties of sandcrete blocks. Journal of Engineering and Applied Sciences. 3 (9) 735-741

[10] Osuji, S. O. and Egbon, B. N. (2015, “Optimizing compressive strength characteristics of hollow building blocks from granite quarry dust and sand", Nigerian Journal of Technology, Vol. 34, No. 3, p. 478 $-483$.

[11] Nigerian Industrial Standards (2003). NIS 444: Quality standard for Ordinary Portland cement. Standard Organization of Nigeria (SON), Lagos.

[12] British Standard Institution, (1985). BS 812-103.1. Testing aggregates. Method of determination of particle size distribution. Sieve tests. London.

[13] British Standard Institution, (2009). BS EN 12390-5. Testing hardened concrete. Flexural strength of test specimens. London. 
[14] British Standard Institution, (2000). BS EN 12390-1. Testing hardened concrete. Shape, dimensions and other requirements for specimens and moulds. London.

[15] British Standard Institution (2009). BS EN 12390 6. Testing hardened concrete. Tensile splitting strength test of specimens. London.

[16] Khamput, P. (2006): A study of compressive strength of concrete using Quarry dust to replace Sand. Technology and Innovation for Sustainable Development Conference, Faculty of Engineering Khon Kaen University, Thailand. pp 108-110.

[17] Ukpata, J. O., Ephraim, M. E. and Akeke, G. A. (2012). Compressive strength of Concrete using lateritic sand and quarry dust as fine aggregate. ARPN Journal of Engineering and Applied Sciences. Vol. 7, No 1, pp 81-92.

[18] American Concrete Institute (1999): Aggregates for Concrete: ACI Education Bulletin E1.

[19] Nigerian Industrial Standards "NIS 87: Standards for Sandcrete blocks", Standard Organization of Nigeria (SON), Lagos, 2004.

[20] Boeck, L., Chaudhuri, K. P. R. and Aggarwal, H. R. (2000). Sandcrete Blocks For buildings: A detailed study on mix compositions, strengths and their costs. The Nigerian Engineer. Vol. 38 No 1, pp 24-33. 